\title{
For coming out of the closets HIV and AIDS and Theology in Brazil
}

\section{André Musskopf ${ }^{1}$}

\begin{abstract}
The HIV and AIDS epidemic arrived in Brazil as a "gay cancer", a narrative created mostly through the media before actual cases were diagnosed. This narrative has remained strong and powerful maintaining the stigma and discrimination against people with HIV and AIDS. Any truthful and honest theological or church response to the epidemic will have to deal with this "ghost" even when the focus is moved from the LGBT community to speak of other vulnerable subjects and groups. The first part of this article shows how the "gay cancer" narrative was constructed in the context of an emerging homosexual movement and major political changes in the country. The second part of the article presents some of the responses in the field of religion in the Brazilian context, how they reinforced the "gay cancer" narrative, but also how more positive answers were given, especially in the early years of the epidemic. It also makes explicit the virtual absence of a systematic theological reflection, even in the context of Latin American Liberation Theology, mostly because of the difficulty in dealing with structural issues that deepen and make more complex class and economic poverty. The third part of the article reports the creation and reactions to the HIV and AIDS prevention campaign "Not even the Saint protects you - Use condom" in the context of the 15th São Paulo GLBT Pride Parade in 2011. The fourth and final part makes some theological remarks emerging from the narrative of the advertising campaign in the search for an out of the closet theology in the context of the HIV and AIDS epidemic.
\end{abstract}

Keywords: HIV and AIDS; Brazil; Religion; Queer theology.

\section{1. "The gay cancer"}

Around 1983, it was expected, only, the confirmation of the presence of the disease in Brazil. And the press waited only for the name of the first victim to produce a headline already prepared beforehand. The headline arrived, finally, exactly in the year of 83 that saw an outbreak of journalistic interest on what was then defined, objectively, as "gay cancer" or "gay plague". ${ }^{2}$

1 Doctor in Theology. Faculdades EST, São Leopoldo, Brazil. Professor of the HIV AND AIDS and Theology in Latin America Project. He can be contacted at asmusskopf@hotmail.com

2 Daniel, Herbert. AIDS no Brasil: a falência dos modelos. In: Daniel, H.; Parker, R. Aids: a Terceira epidemia. São Paulo: Iglu, 1991. p. 32. Apud GALVÃo, Jane. AIDS no Brasil. Rio de Janeiro: ABIA; São Paulo: Ed. 34, 2000. p. 56. All quotes in other language than English are the author's own translation. 
The narrative that marked (and still marks) most of the social imaginary of HIV and AIDS in Brazil regards it as a "gay disease". This narrative, not necessarily the only one available everywhere, defined the ways in which the emergence of HIV and AIDS was understood and the answers that were given to it. Of course, soon enough, other actors became known as affected/infected by the virus and the immunodeficiency syndrome, not less guilty or blamable for their fate - such as drug users, prostitutes and, who would have guessed, Haitians. ${ }^{3}$ It may seem strange to recall those years and facts since it became politically correct to "know" and "speak" of HIV and AIDS as something everyone is "vulnerable" to, at least for those who have been active in fighting the consequences of the "new disease". But somehow, and many studies have been carried out showing how this came to be, the stigma and discrimination born from this narrative are very still alive, especially when it comes to religious people and institutions. This may explain why many people do not take the test to know their serology, many do not start or continue their treatment for the fear of letting other people know or "suspect", many people hide it from their family, friends, coworkers and "suffer" their condition in solitude and, most of all, very few dare to talk to their pastors or let their community of faith know about it. After all, there is something to be suspicious about, there is something to hide, there is something that shouldn't have been done - unless, of course, you are "an innocent victim" worth of compassion - whatever that means.

The studies carried out about the impact of the media in the "invention"4 of the HIV and AIDS epidemic, show that, in Brazil, the disease arrived before it was actually affecting the population through the news coming mainly from the northern hemisphere. So, it has been characterized by some authors as "mal de folhetim" [soap opera evil].5

3 Those, along with hemophiliacs, were considered "risk groups" in the early years of the epidemic. See Bastos, Francisco Inácio. Aids na Terceira década. Rio de Janeiro: Editora Fiocruz, 2006. p. 29-43, where the author speaks of the "modern tale" of the $4 \mathrm{H}$ (homosexuals, Haitians, hookers, heroin users) and how this tale was (falsely) constructed.

4 I use here the term "invention" as it was used by authors such as Westhelle and Chaui to speak of the mythic origin of Brazil. According to Chauí, Marilena. Brasil: Mito fundador e sociedade autoritária. 5 imp. São Paulo: Editora Perseu Abramo, 2000, p. 57: “Those were not ‘discoveries' or, as it was said in the XVI century, 'findings'. They are historical inventions and cultural constructions [...]. Brazil was instituted as Portugal's colony and invented as 'land blessed by God". Also Westhelle, Vitor. Voces de protesta en América Latina. México: CETPJDR/Lutheran School of Theology, 2000, p. 30: "The conquerors 'knew' the inhabitants of the New World, even before their meeting. When arriving the ships came full of answers to a question that had been formulated on Iberian ground: Who is the other?". In the case of the AIDS epidemic, however, the answers were "invented" on Brazilian ground before the disease actually arrived, not less influenced by the meanings constructed in foreign lands.

5 Expression crafted by Carrara, Sérgio; Moraes, Claudia. Um mal de folhetim. Comunicações do Iser, Rio de Janeiro, vol. 4, no 17, p. 20-26, dez 1995, mentioned in Galvão, Jane. AIDS no Brasil - A agenda de construção de uma epidemia. Rio de Janeiro: ABIA; São Paulo: Ed. 34, 2000. p. 48. 
The period between 1981 and 1984 marks the way AIDS "arrived" in Brazil: it will not be through the cases of people with AIDS identified in the country, but through the report of the disease through the media. As in other countries, the media, in Brazil, had a fundamental role in making public the unknown disease. But one characteristic of AIDS in Brazil, differently from the United States, for example, is that the new illness becomes known and popular before the cases of AIDS were officially reported. ${ }^{6}$

It is not difficult to guess, for those who were not the actual audience of those messages, that this meant a sensationalist and prejudiced approach, signaling to the wrongdoers (mainly gay men) as the responsible ones for putting Brazil on the AIDS map. ${ }^{7}$ Besides being associated with homosexuality, AIDS was also seen as something coming from outside the country (foreigner) ${ }^{8}$, which is common in such situations, and the way it was treated by the media had also to do with the Brazilian political context.

Specifically in Brazil of the 80's, which marks the beginning of the country's redemocratization process, the media has a fundamental role. In that moment, AIDS, then called in the media by names such as "homosexual disease" and "gay cancer", was the perfect news for the political opening of the country: it referred to the 70's in what was most "scandalous" - sex and drugs -, without mentioning the political context. In this reading of AIDS done by a good portion of the Brazilian media, one of the main legacies of the 70's was a virus, transmitted through a certain behavior, mostly sexual. Reports that mentioned the "desbunde" of the 70's, the liberalization of habits, and how AIDS was like a "cold shower" on the libertarian theories of the 70's. The interesting is that such an analysis was related to the United States, since Brazil was coming out of the period of military regime and had not gone through, so strongly, the situations described. But since the representation of AIDS mentioned a disease that came from "outside", and the sick people who made the news in the media had traveled abroad, mostly to the United States, this argument seemed to make sense. ${ }^{9}$

6 Galvão, 2000, p. 48.

7 Galvão, 2000, p. 51. See complete study in GALVÃO, Jane. AIDS e a imprensa: um estudo de Antropologia Social. Thesis (Masters in Social Anthropology) - Graduate Program in Social Anthropology, Museu Nacional, Universidade Federal do Rio de Janeiro, 1992. Mimeo.

8 According to Galvão, 2000, p. 55-56, "Described in the media as different and foreigner, the new disease seemed not to bother Brazilians much. What would Brazil have to do with a virus described as attacking north-American homosexuals that used poppers in long nights out at saunas, discos and dark rooms of San Francisco and New York? But, in 1983, this picture starts to change. AIDS cases are diagnosed in São Paulo, despite the fact that the virus was still seen as "foreigner", since Brazilians who are sick (and that appear in the newspapers) are described as having been traveling abroad, mainly to the United States, belonging to the middle class and, above all, " homosexuals".

9 Galvão, 2000, p. 52-53. 
This is not to say that the AIDS epidemic has nothing to do with homosexuality, or more specifically, with the LGBT community, in Brazil or in the United States (not withstanding other possible social histories elsewhere, especially in the African continent, being affected by it long before it reached the news in the northern hemispher $\left.\mathrm{e}^{10}\right)$. The narrative constructed of AIDS as a "gay disease" gathered the somewhat coincidental (historically speaking) fact that the gay community was actually strongly affected by it with old and new ghosts and prejudices. ${ }^{11}$ Referring to the "gay scene" in Western societies, especially in the United States, born out of strong social movements emerging during the 60's and its identity politics, Francisco Inácio Bastos states:

It was exactly this lively, dynamic scene that had sexuality as an essential and defining element of personal identities, that was remarkably affected by the dissemination of HIV, probably at the end of the 70's (with evident reflexes in the subsequent decade). [...]

It is a badly-told history, that incurs in and essentialism at all strange to biology, since, I repeat, the virus aims to (in a non-purposeful way, it is obvious) merely persist, and found shelter in this strongly interactive, interconnected scene, where sexual relations (at the time, almost always unprotected) contributed strongly to establish affective ties and demarcate identities. ${ }^{12}$

As stated above, the political situation in Brazil was not the same as in the United States, including the development of social movements and a gay liberation movement in particular. The 70's certainly were a period marked by resistance to the military dictatorship, and also the emergence of countercultural movements that questioned traditional moral values that were understood (and actually were) part of the authoritarian system in power. ${ }^{13}$ Even though homosexuality has been part of

${ }_{10}$ In relation to this, showing how the relation between HIV and AIDS and homosexuality was constructed, Bastos, Francisco Inácio. Aids na terceira década. Rio de Janeiro: Ed. Fiocruz, 2006. p. 33, states that "Meanwhile, the epidemic progressed rapidly in the sub-Saharan Africa in the absence of any gay scene (obviously, this does not mean that there were no male homosexuals in Africa, but certainly not a gay scene in the Western models, exception, to the time, the South-African big cities), basically through heterosexual relations without the use of condoms".

11 According to Sampaio, Tânia Mara. Aids e religião: aproximações ao tema. Impulso, Piracicaba: Editora Unimep, vol. 13, no. 32, set.-dez, 2002, p. 23, “Aids in its historical beginning, from 1983 on, brought to light a repertoire of prejudices and stigmatizations that were or sleeping in the consciousness of many people or silenced purposefully by others". She compares the emergence of Aids to the reality of leprosy in the Medieval Ages (p. 25). See also Nascimento, Dilene Raimundo do. As pestes do século XX: tuberculose e Aids no Brasil, uma história comparada. Rio de Janeiro: Ed. Fiocruz, 2005.

12 Bastos, 2006, p. 32, 34.

${ }^{13}$ One of those movements became known as "tropicalismo". See, for example, Barros, Patrícia Marcon- 
Brazilian history since before, during and also after the colonial period ${ }^{14}$, it was not before the end of the 70's that an actual social movement, with a political agenda, started to emerge. ${ }^{15}$ It was precisely with the mitigation of the military dictatorship that homosexual groups and tools of political action were able to emerge and organize more solidly.

This way, it was the incipient Brazilian homosexual movement that had to face the new challenges arising with the AIDS epidemic and its association with homosexuality, in a completely adverse political context. ${ }^{16}$ In order to confront the epidemic a stronger organization process and the formation of a battlefront resulted in the creation of countless Non-Governmental Organizations throughout the country. Many of those organizations were formed by homosexual people or organizations that took also on this struggle in the fighting of the epidemic. ${ }^{17}$ The same happened in the academic field and the feminist, gender and studies on sexuality were impacted by the epidemic and the answers needed for its confrontation. ${ }^{18}$ These developments were responsible

des de. A nova consciência dos trópicos e a imprensa do desbunde. Available at: http://tropicalia. com.br/leituras-complementares/a-nova-consciencia-nos-tropicos-e-a-imprensa-do-desbunde. Acessed on: February 20, 2013. According to Oliveira, Ana. Identisignificados - Movimento. "Irreverent, the Tropicália transformed the criteria of taste existing, not only regarding the music and politics, but also the moral and behavior, body, sex and clothing. The hippie counterculture was assimilated, with the adoption of the fashion style of long curly hair and scandalously colorful clothes" (Available at: http://tropicalia.com.br/identifisignificados/movimento. Acessed on: February 20, 2013).

${ }^{14}$ See Mott, Luiz. Escravidão e homossexualidade. In: Vainfas, Ronaldo (org.). História e sexualidade no Brasil. Rio de Janeiro: Graal, 1986. p. 19-40; Trevisan, João Silvério. Devassos no paraíso: A homossexualidade no Brasil, da colônia à atualidade. Rio de Janeiro: Rcord, 2000; Green, James N.; Trindade, Ronaldo (org.). Homossexualismo em São Paulo. São Paulo: Editora Unesp, 2005.

15 See Green, James N. Além do carnaval: A homossexualidade masculina no Brasil do século XX. São Paulo: Unesp, 2000, p. 391-449; Parker, Richard. Abaixo do Equador: Culturas do desejo, homossexualidade masculina e comunidade gay no Brasil. Rio de Janeiro: Record, 2002; Trevisan, 2000, p. 335-351.

${ }^{16}$ On the relation between homosexuality and AIDS see: Abia. Homossexualidade e AIDS no Brasil: Catálogo do Centro de Documentação e Recursos da Abia. Rio de Janeiro: Abia, 2001; Terto Jr., Veriano. Reinventando a vida: histórias sobre homossexualidade e AIDS no Brasil. Tese de Doutorado. Rio de Janeiro: Universidade Estadual do Rio de Janeiro, 1997; Terto Jr. Veriano. 0 movimento social da AIDS e as novas identidades sexuais. In: Parker, Richard; Corrêa, Sonia (org.). Sexualidade e política na América Latina. Rio de Janeiro: ABIA, 2003. p. 97-100.

17 According to Parker, 2002, p. 76: “With the emergence of Aids between the beginning and mid 80's, and the continuous association between HIV and AIDS and the experience of gay and bissexual men in Brazil, the social and political mobilization relatively gradual that was taking place in the emerging gay community during more than a decade started to follow hand in hand with the intense defense of the cause of Aids"

${ }^{18}$ According to Citeli, Maria Teresa. A pesquisa sobre sexualidade e direitos sexuais no Brasil (19902002): Revisão crítica. Rio de Janeiro: CEPESC, 2005. p. 67: "the Social Sciences (in Brazil as much as in na international perspective) were deeply affected and renewed by the researches about AIDS, accomplished at the end of the 80 's. The wide range of innovations that marked the returning of the studies about human sexuality that took place in the last 20 years goes from the kind of information 
for the way HIV and AIDS was handled in Brazil, also considering all the advances earned in terms of public policy, which are a direct result of the militant work of - in its majority - "gay-related organizations and movements" - the perfect antidote for the "gay related immunodeficiency syndrome - GRID" (one of the early names given to the disease by north-American specialists).

We reached a point in the history of the epidemic in which there is a strong effort to dissociate AIDS from homosexuality, campaigning that it is a problem that affects all people everywhere and that nobody is untouchable, unless each individual has the correct information and adopts safe practices (sexually or otherwise). This way, the "AIDS issue" has become more comfortable to deal with, especially in the context of churches and theological reflection. We are now looking for (old) theological answers being polite enough not to ask questions about how, when, with whom people were or are being infected. They just became one more people in the list of the stigmatized, marginalized, excluded, poor ones that theologians and church leaders try to fit in the box of the ones we should have compassion and solidarity for.

Even when we do not to forget what the epidemic has (still) to do with homosexuality and how it affected (and still affects) the LGBT community in Brazil or elsewhere in the past, unconsciously still believing it is "their" fault, we (at least the ones seeking actual impact in the confronting of the epidemic, and not just reproducing heterocentric parodies) avoid speaking of things such as sexual or any other practices or life experiences that do not fit our hygienic canon, heterocentrically, patriarchally, classistically or racially ordered. Although, at least in the Brazilian case, this has not meant that the same takes place in terms of public policy, given the attention and actions taken considering the effects of the epidemic in the LGBT community, religious groups and their anti-homosexual theologies have tried (and in some cases succeeded) in interfering in this kind of policy, while preaching in favor of confronting the epidemic on their own terms, which means, once again, avoiding the systemic issues involved in it. It is my argument that a truthful and honest theology and church action regarding HIV and AIDS will not be able to rise unless those issues are dealt with, overcoming the homosexual phantasmagoric narrative, not by hiding it in the closets, but by bringing them forth with all the implications for the reconstruction of human existence in times of AIDS. We got the tools. We just need not to let our bodies not lie. ${ }^{19}$

collected to the methodological approaches, the interdisciplinary stance and the strong connection between researchers, activists and people with the disease [...] - all of this generated a large amount of academic production, by isolated researchers as well as through the integration of knots of research network".

${ }^{19}$ Hunt, Mary. Bodies don't lie: A feminist theological perspective on embodiment. Available at: http:// 


\section{What's got theology and the church to do with it?}

It is not the intention of this article to reinforce the idea that the HIV and AIDS epidemic is exclusively related to "homosexuality" or to people with reprehensible behavior, character or life style (whichever terms one may use to label peoples life experiences). There is, however, something to say about the ghosts awakened by the epidemic related to homosexuality in particular and sexuality in general that must be dealt with if any relevant theological and ecclesiastical response will be given to the epidemic. So, in some sense, to think about HIV and AIDS and Theology in Brazil it is necessary to discuss the relation established between the theological and ecclesiastical practices and discourses and the epidemic since its emergence as a social issue.

It will not surprise anybody that the narrative of AIDS as a "gay disease" owns a lot to religious discourses and practices evoking the idea of a divine punishment. In a context in which homosexuality was still treated commonly as a disease, reminiscent ideas from the medicalization process unleashed in the second half of the XIX century ${ }^{20}$ offered the common language to reinforce the pathological discourse with a special touch coming from religious institutions mixing up (not coincidentally) a clinical diagnosis with a moral judgment easily turned into a moralizing campaign of which the damaging effects are now very well known. ${ }^{21}$ It is not the intention here to recall all the diabolic ways in which AIDS-homosexuality-disease-God's punishment were elaborated theologically (even because of its simplistic elaboration it is not difficult to understand it - while not agreeing with it), but emblematically it will suffice to mention Jane Galvão's reflection:

But it is undeniable that AIDS enabled the rearticulating of moral notions expressed in the binomials sex/death and dissoluteness/disease, offering, even be-

www.wftl.org/pdf/063.pdf. Accessed on February 20, 2013. Reflecting on the issue of embodiment in Theology she challenges: "I think we need to explore embodiment theologically as if it were a matter of life or death, because it is. As theologians our task is not only to seek meaning but to make change. Our bodies must not lie either".

20 Trevisan, 2000, discusses, in Chapter 2, the medical/scientific studies about homosexuality evidencing their false neutrality and their consequences. Later on (chapter 4 - "Entra em cena o homossexualimo") he shows how this discussion took place in the Brazilian medical filed, especially by hygienist physicians. He states: "in whatever case, the goal was thoroughly the same: reach a scientific definition so that the specialist could intervene, physical or psychologically, against the anomaly" ( $p$. 178). For a wider discussion on the medicalization of homosexuality see Greenbeerg, David F. The construction of homosexuality. Chicago: The University of Chicago Press, 1988. p. 397-433.

${ }^{21}$ Although homosexuality is no longer considered a disease by the World Health Organization since 1990, and by several other professional bodies (for example the National Council of Medicine - 1985 - and the National Council of Psychology - 1999 - in Brazil), the association between homosexuality and illness is very still alive, supported mainly by organizations connected to religious beliefs. 
fore concrete actions were implemented, an excellent opportunity to recall issues so dear to some religions. The biblical reflections resulting heated the debate in the beginning of the epidemic, being the Bible re-read with emphasis on a wide range of answers that we could call negative in face of the disease and the sick.

As an example of this point, I mention one of the earliest and most public religious manifestations against AIDS and its sick, that came from the Catholic Church when, in 1985, Don Eugênio de Araújo Salles, Rio de Janeiro's Archbishop-Cardinal, wrote his article "The Evil and the cowardice of the Good ones" (Salles, 1985). In the article, Dom Eugênio approaches AIDS as a "divine punishment"; a retaliation from nature against the "inversions" that were taking place in the field of sexuality. ${ }^{22}$

This kind of discourse and practice was very effective and influenced the kind of involvement the churches had in the confrontation of the epidemic and the kind of theological reflection (not) done on it. This means that any effective movement to reverse this will have to overcome the suspicions of sectors who historically took over the challenge of facing the epidemic (such as the LGBT movement, non-governmental organizations and even government agencies), and will require a hard and painful work on the side of the ones who believe in the importance and potential of the religious institutions and theology in the confrontation of the epidemic.

The religious responses to the epidemic, however, cannot be reduced to this kind of message, although they were predominant and most effective. Several experiences that took place from early on rehearsed another theology and church practice that has to be made visible and can be an important tool in reflecting on the challenges still ahead. According to Brazilian activist and researcher Jane Galvão, it is possible to identify, from the 90's on, the work of churches and religious groups in at least three areas in Brazil: the creation of support houses and actions in partnership with NGO, home care for people with HIV and AIDS and debate forums including consultations, meetings and courses, as well as the publication of materials related to HIV and AIDS. ${ }^{23}$

In the Brazilian context it is also important to mention the role played by AfroBrazilian religions. In the beginning of the epidemic there was no substantial involvement. This was due, particularly, to the discrimination and prejudice faced by those religious traditions long before the emergence of the epidemic. Another reason for the discrimination of those religious traditions is connected to the par-

${ }^{22}$ Galvão, Jane. As respostas religiosas frente à epidemia de HIV and AIDS no Brasil. In: Parker, Richard (org.). Políticas, instituições e AIDS: enfrentando a epidemia no Brasil. Rio de Janeiro: Abia, 1997. p. 113-114.

${ }^{23}$ Galvão, 1997. p. 109-134. 
ticipation of homosexuals. ${ }^{24}$ Once again, the relation established between AIDS and homosexuality, now connected to marginalized and discriminated against religious traditions, reinforced the narrative of AIDS as a gay disease, and prevented a proactive position by those groups who sought public recognition.

It is also important to mention that civil society and organizations and government agencies outside the ecclesiastical and theological world have seen in religion and religious institutions possible partners in confronting the epidemic and have made efforts to bring churches and religions to the confrontation of the epidemic. ${ }^{25}$ This shows how important the participation of churches and religions is seen in the struggle against AIDS. It is true that more recent initiatives and projects accomplished by religious groups have had an impact in the understanding of the epidemic, the background issues that cause specific social groups to be more vulnerable to it and what kind of responses churches and religion can give to it. ${ }^{26}$

It is undeniable that the initiatives taken have produced diverse and innovative theological perspectives, given that theology is not only produced in academic circles, but from the movement of people of faith, communities and churches. Countless pamphlets, journals, booklets have been edited by groups and organizations and even churches about the HIV and AIDS epidemic. ${ }^{27}$ Much of this theology, however, is not systematized and available for education and study. In other cases, what has been produced is difficult to access or made invisible, precisely because it questions normative discourses and practices of the institutions that maintain the structures that, at the same time, are responsible for the spreading of the epi-

${ }^{24}$ Galvão, 1997, 115. The relation between Afro-Brazilian religions and homosexuality has been object of several studies. See: Fry, Peter. Pra inglês ver. Rio de Janeiro: Zahar, 1982.

${ }^{25}$ At a governmental level, in 2006 The National Program on STD/AIDS of the Ministry of Health organized the Seminar on AIDS and Religion. In the same way, statewide governments have articulated meetings and networks of religions to discuss ways to act together (See Múscari, Marcello Felipe de Jesus. A dupla construção: A resposta à AIDS e a regulação do religioso no '10 Seminário Aids e religião do Rio Grande do Sul'. Trabalho de Conclusão de Curso. Porto Alegre: UFRGS, 2011. Available at: http://www.lume.ufrgs.br/bitstream/handle/10183/40398/000827246.pdf?sequence=1. Acessed on 28/05/12). In terms of civil society, the Brazilian Interdiciplinary Association on AIDS (ABIA) developed, between 2005 and 2010, in five Brazilian capitals the project Religious responses to the HIV and AIDS epidemic in Brazil (See ABIA. Respostas religiosas ao HIV AND AIDS no Brasil. Rio de Janeiro: ABIA, 2010. Available at: http://www.abiaids.org.br/_img/media/Livreto\%20 Religi\%C3\%B5es\%20completo.pdf. Acessed on: 28/05/12).

${ }^{26}$ One very recent example is the project "Studies and research on Theology and HIV and AIDS in Latin America, carried out in four theological institutions in Latin America, including Faculdades EST, in Brazil. See the webpage http://www.teologiaysida.org/.

${ }^{27}$ An organization that has worked on the issue of HIV and AIDS is Catholics for the Right to Choose. See Orozco, Yury Puello. Mulheres, AIDS e religião. São Paulo: Católicas pelo Direito de Decidir, 2002. Also the Roman Catholic AIDS Pastoral: Conferência Nacional Dos Bispos Do Brasil. Pastoral DST/ Aids. Viu e teve compaixão. Igreja e Aids. Fortaleza: CNBB - Pastoral DST/Aids. 
demic. Deep theological reflections that widen and expand those elaborations are still needed.

Some Latin America theologians have already worked with the reality of the HIV and AIDS epidemic. ${ }^{28}$ Here and there it is possible to find articles and texts that debate those issues in a theological perspective. ${ }^{29}$ In the context of Latin American Liberation Theology it is notable that only in the 90's some reflections of theologians started to appear on this issue and very seldom, mostly advocating solidarity. ${ }^{30}$ It is notable, at the same time, that already in 1991 and article was published in the collection "René Girard with Liberation theologians", by the British gay theologian then living in Brazil James Alison, entitled "AIDS as a place of revelation". ${ }^{31}$ Since then, not much, however, can be found in the Brazilian and Latin American theology that faces the actual issues involved in the epidemic since its beginning and more recently.

In a certain way, it is not that strange that the HIV and AIDS epidemic has not become a central theme for liberation theologians. Considering the fact that the narrative of the epidemic in the Americas has been connected to the LGBT community, it was required, from the point of view of theology, approaches that dealt with gender and sexuality issues. According to Ivan Perez Hernández:

... the founding generation of TsL [Liberation Theologies] was formed fundamentally by white men who dialogued mainly about the theological doing [quehacer] (...) with class analysis. If for this generation it was already costly the work of enriching with the liberating demands of the groups mentioned above their admirable initial contributions, much more hard-working was for them to let go even more from sexism and hetero-sexism - both so much imbricated - that characterized both the left of the sub-continent as well as their churches. (...) it is not until the emergence of the AIDS epidemic, in the beginning of the eighties, that critical public discussions are generated about sexuality and homosexuality in countries where the Catholic Church and/or military regimes exercised an almost total control over how those issues should be discussed in the public sphere. ${ }^{32}$

${ }^{28}$ One of the Brazilian theologians who has more systematically worked on the theme is José Trasferetti. See, for example: Trasferetti, José Antônio; Lima, Lívia Ribeiro. Teologia, sexualidade e Aids. Aparecida, SP: Santuário, 2009.

${ }^{29}$ For example, Pereira, Nancy Cardoso. Igrejas e Aids (2): perspectivas bíblicas e pastorais. Rio de Janeiro: Instituto de Estudos de Religião, 1990.

${ }^{30}$ See reflection by Hernandez, Ivan Perez. Teologías de la Liberación y minorias sexuales em America Latina y el Caribe. In: Trasferetti, José (org.). Teologia e sexualidade. Campinas: Átomo, 2004. p. 123s. Also the article by Alves, Rubem. AIDS. Tempo e Presença, Vol./No. 269 , p. 52-53, 1993.

${ }^{31}$ Alison, James. AIDS como lugar de revelação. In: Assman, Hugo (Ed.). René Girard com teólogas da libertação. Petrópolis/Piracicaba: Vozes/UNIMEP, 1991. p. 309.

32 Hernandez, 2004, p. 108-109. 
But why at all should theology and religions in general be concerned with the HIV and AIDS epidemic? What is it with this virus and this disease that would require special attention from churches and theology? Isn't the "gay disease" or the "God's punishment" (pseudo)theology enough to explain its reality and indicate the way to engage in it? Those may seem irrelevant questions given the discussion done up to now, and especially with the ways we came to understand the epidemic in our days. But it might surprise some to see how church leaders or even theologians still deny (at least unconsciously) that AIDS is something that affects the churches, and when there is some kind of awareness it will mostly be in terms of compassion for sinners who do not lived out the religious virtues or innocent victims who were trapped.

The concept of "vulnerability" has expressed the idea that some individuals or groups may become more easily affected by the epidemic because of structural issues over which those individuals and groups have not (necessarily) control. In the last decade, especially in the social movements and public policies, the changing "face" of the AIDS epidemic has been discussed, showing that more and more poor people, women, youth, elderly, racial/ethnic groups, for example, have been infected. Although those groups may produce a more kindly look from theology and the church - exception made to the old "risk groups" such as homosexuals, prostitutes, drug users and promiscuous people in general -, precisely because there are structural issues at the base of those numbers, more than kindness and compassion will be needed in order for theology and the church to become relevant in the struggle against AIDS. Issues such as classism, sexism, racism, and the old and good homophobia and heterosexism will have to be dealt with. Those are the real issues for theology and the churches and they challenge traditional theology that fetishizes reality and out of metaphysical concepts about how people should be seek to give answers to questions that have not been made, or that are, at least, an escape from the real lives of people struggling with HIV and AIDS.

\section{3. "Not even the Saint protects you" - a theology born in the struggle}

In 2011, the São Paulo LGBT Pride Parade completed 15 years of existence as the largest Pride Parade in the world. The theme chosen for the 15th anniversary of the event was "Love one another: enough of homophobia!". The use of an alleged religious (biblical) passage caused in itself reactions from religious leaders and churches (mostly Roman Catholic and Evangelical/Pentecostal) claiming that the Association of the GLBT Pride Parade (APOGLBT) was usurping improperly a religious (Christian) slogan. ${ }^{33}$ If that was not enough, during the event, 170 posters were exposed along

${ }^{33}$ See Cardeal Scherer critica desrespeito à fé católica na parada gay em São Paulo. Available at: 
the Paulista Avenue (circuit of the Parade) that read "Not even the Saint protects you - Use condom". More than that, the posters pictured male figures described as "muscled", "half naked", representing Roman Catholic Saints..$^{34}$ The reaction, again, accused the organization responsible for the campaign. "The idea was criticized by the Cardinal Dom Odilo Pedro Scherer, metropolitan Archbishop of São Paulo, who considered the campaign 'unfortunate, mocking and disrespectful'. 'It is a mocking way of using images of saints, that for us deserve all respect". ${ }^{35}$

The campaign was sponsored by the organization of the Parade and produced by photographer Ronaldo Gutierrez and publicist Eduardo Lima. It all started with the personal passion of the photographer who is a lover of Sacred Art, although not Catholic. According to him, "I like saints, read their biographies and even studied the Bible for many years. The histories are captivating. I put all this together with my liking for painting and did this work for myself'. ${ }^{36}$ So, the pictures were not intended originally for the prevention campaign.$^{37}$ Nevertheless, Ronaldo's work came out of his personal experience with the religious narratives and in face of the reactions by religious authorities he stated:

It is not with religion that I am messing, it is with the people who say that they boss it. As I said, I think that the life of the saints is an example of goodness and love for the neighbor, but this is not what I see in the ones who command. I know that the majority of Catholics is formed by very good people and who want to help. Others, unfortunately, those who have the communication means, are prejudiced and ignorant. ${ }^{38}$

In his evaluation of the reception of his work he distinguishes between the "Catholic people" and "people who say that they boss it, command and own the means". And

http:// www.acidigital.com/noticia.php?id=22070. Acessed on March 3rd 2013. Cardinal Dom OdiIo Scherer stated: "Instumentalize those sacred words to justify the opposite of what they mean is profoundly disrespectful and offensive, in relation to that which Christians have as very sacred and truthful".

${ }^{34}$ See Santos da polêmica. Available at: http://www.doistercos.com.br/santos-da-pole/. Accessed on March 4th, 2013.

${ }^{35}$ Arcebispo de SP critica o uso de imagens de santos na Parada Gay. Available at: http://g1.globo. com/sao-paulo/noticia/2011/06/arcebispo-de-sp-critica-0-uso-de-imagens-de-santos-na-parada-gay.html. Accessed on: March 3rd, 2013.

${ }^{36}$ Llistó, Paco. Fotógrafo se diz ameaçado após campanha de prevenção com imagens sacras durante Parada Gay. Published on June 27th, 2011. Available at: http://acapa.virgula.uol.com.br/mobile/ noticia.asp?codigo=14015. Accessed on: March 3rd, 2013.

${ }^{37}$ See a gallery of the pictures developed by the photographer: Confira galeria com as imagens dos santos que causaram polêmica na Parada de SP. Available at: http://acapa.virgula.uol.com.br/ cultura/confira-galeria-com-as-imagens-dos-santos-que-causaram-polemica-na-parada-desp/3/8/14038. Accessed on: March 4th, 2013.

38 Llistó, 2011. 
his partner in the campaign, Eduardo Lima, sentences: "If the Catholic Church didn't like it, forgive me, but I don't need her authorization to speak". In an interview, he explains how the campaign came to be. According to him, besides his work with the São Paulo Pocket Guide ${ }^{39}$ he had been engaged before in prevention campaigns understanding it as a matter of citizenship. It was his idea to use Ronaldo's photographs in a prevention campaign that, besides being exposed in the posters on Paulista Avenue during the LGBT Pride Parade, also were imprinted on packages that contained condoms to be easily put away in people's pockets. According to him:

That's why the pocket concept that I always bring and hammer and repeat over and over. Because what do you keep in your pocket? Something of value. You put away the condom that is important. To offer a condom to someone is an act of love, of caring. So all this is involved in my work, it is part of me, wants to overflow. If I can speak to people or do something that involves people and provokes really. I feel that my campaign with the saints did provoke people and many changed their opinion. ${ }^{40}$

Putting together the obvious (homo) erotic appeal of the pictures and the use of the condom in the recreation of religious icons for the prevention of AIDS is judged by religious authorities as being out of line (to say the least). It is hard to evaluate how much the "Catholic community" actually felt offended by it and how much the ones "who say they boss it" did - representing traditional theological discourses that, in this particular case, the Roman Catholic Church, forbid the use of condoms and consider LGBT people to be "intrinsically disordered". Even though it might seem that the interest of both Ronaldo and Eduardo are not necessarily theological, one might argue that a different theological understanding is underneath this approach. Let's see the position of Ideraldo Beltrame, then president of the APOGLBT, the organization that sponsored the campaign. This is what he thinks about the images of Saints and their communication potential:

The image of Saint Sebastian itself produced by the Catholic Church herself is in itself an eroticized image. It is a naked body, unfurled, covered only by some pieces of fabric and arrowed in the center of the body. For a long time I myself had a Catholic Christian raising and believed that the saints fell from heaven, that they were sacred. One day a priest gave me a book about my protection saint, the saint of my faith which was Saint Rita of Cascia. And I found out that she was married, forced by her father,

${ }^{39}$ See the webpage http://www.saopaulodebolso.com.br/portal/. Accessed on March 4th, 2013.

${ }^{40}$ Revista Friday. Entrevista: Eduardo Lima: Proteção acima de religião. Available at: http://www.revistafriday.com.br/2012/06/entrevista-eduardo-lima-protecao-cima.html. Accessed on March 3rd, 2013. 
with an extremely violent man who probably might have beaten her, had two children with him against her will and I demystified a little the idea of the saint itself. ${ }^{41}$

This understanding is, then, applied to what is seen as an urgent element of reality and creates a different message.

When using and making the campaign "Not even the Saint protects you - Use condom" I thought as Professor Doctor in public health, in the epidemiological data of the state of São Paulo that show that there is an increase in the infection by HIV in the younger age group, between 14 and 24 years old, a group to which this religious morality and religion itself has distanced extremely..$^{42}[\ldots]$ We used models that are aesthetic models for an aesthetics that this youth understands. It is clear that by reproducing this campaign our aim is the insistence and obstinacy of the Catholic Church in recommending the non-use of the preservative in the case of prevention to STD, AIDS and hepatitis. So we were concerned with producing a campaign that had a focus, that had a language close to the public I want to get to. Probably if I put the saints with the image that is produced, kind of sacred, and sacramental, and as if it was something not human, another experience, maybe they would not have the same look on it.

One could question the "aesthetics" Ideraldo refers to, since the models follow a body pattern that is connected to bodybuilding and the idealization of a perfect (white) body, another form of fitting people into normative patterns, but the repercussion of the campaign shows that it was not only effective in advertising grounds, but also in questioning a specific theological discourse so much as to be publicly accused of mockery and being a scandal. On this, Ideraldo comments:

Those are instruments, tools that may seem sometimes at first sight as being offensive. Now, the social movement of struggle does not exist without polemics. When a landless person invades a piece of land that is not productive, he also causes polemics, he also scares society for what he does. Homosexuals cannot, without causing impact, accomplish any transformation or change.

Again, it is hard to evaluate how much transformation and change this campaign actually produced. The fact is that from the struggle against AIDS and for civil rights

${ }^{41}$ Ninguém é tão santo assim. Video available at: http://nemsantoteprotege.blogspot.com. br/2011/12/ninguem-e-tao-santo-assim.html. Accessed on: March 3rd, 2013. The following quotes are part of the same video.

${ }^{42}$ During the interview Ideraldo is interrupted by the interviewer that asks him if "there was the need to expose the saints in that way, without clothes, creating a situation of disrespect with the Catholic community". 
for the LGBT community a new understanding of religious symbols is born and a different theology is produced. This is a theology that comes out of the closet taking seriously the "homosexual issue" in the context of the HIV and AIDS epidemic and exposing the theological and ecclesiastical discourse and practice that would like to avoid the core issues of the epidemic. In Ideraldo's discourse we have all the elements for a theological response to the HIV and AIDS epidemic that dares to come out of the closet. We got reality and the subject - youth being infected by HIV and AIDS; we got Bible and tradition - the interpretation of the saints; we got method - recreation (which is named as mockery or scandal); we got purpose/ utopia: transformation and change. It's Liberation Theology!

One should not forget that the "Not even the Saint protects you - Use condom" was wrapped, in the context of 2011 São Paulo LGBT Pride Parade, in the theme "Love one another: enough of homophobia!". In this spirit the Koinonia - Ecumenical Presence and Service (an ecumenical organization), the Ecumenical Youth Network (REJU) and the Holy Trinity Anglican Parish (São Paulo) created the campaign "Love casts out fear" (1 John 4.18) that aimed to "show solidarity for the symbolic and physical aggressions, especially those practiced by religious leaders" ${ }^{43}$ As an outcome of this campaign the "Front of religious leaders against homophobia" was created and a group of people connected to this Front opened the 15th São Paulo Gay Pride Parade. ${ }^{44}$ This fact did not receive the same attention from the media, but those religious leaders joining the struggle against homophobia were certainly not shocked by the posters of the Saints that opened their way as they paraded down Paulista Avenue.

\section{On skeletons hidden in the cupboard, no-bodies and pocket theologies - Queering "the issue"}

Mariology is an important field in Latin American Theology and popular religiosity. In several ways, the traditional image of Mary has been questioned for being used to maintain women in a position of submission and subservience. Part of the

${ }^{43}$ Evangelista, Márcia. "O amor lança fora o medo...". Published on July 21st, 2011. Abailable at: http://www.koinonia.org.br/comunicacao-noticias-detalhes.asp?cod=1615. Accessed on March 4th, 2013. In 2012, this became a national campaign against all forms of intolerance. "The campaign seeks to alert people against any kind of intolerance and, mainly, is an action against homophobia. It is intended also to promote the defense of the human rights, the reduction of discrimination rates, gender equity; the adherence to ambulatorial treatment and to the HIV testing" (Campanha: 0 Amor Lança Fora Todo o Medo. Available at: http://www.koinonia.org.br/campanha_amor.asp. Accessed on: March 4th, 2013).

44 In the context of the 15th São Paulo LGBT Pride Parade, the campaign "Love casts out fear" sponsored a number of activities, including a panel on "Religion and homoaffectivity". See Tunes, Suzel. Religiosos apoiam luta de homossexuais. Available at: http://www.koinonia.org.br/comunicacao-noticiasdetalhes. asp? cod=1602. Accessed on March 4th, 2013. 
power to accomplish that comes, precisely, from the fact that she is described with non-human characteristics, or at least with characteristics that are impossible for women, in their daily lives to reconcile (such as being virgin and mother at the same time). In her effort to deconstruct (indecent) the traditional Latin American Mariology, Marcella Althaus-Reid asks the question: "Are there any skeletons hidden in the Virginal cupboard?" ${ }^{45}$. According to her:

The process of becoming human is related to that permanent need to claim our own identity in community. Concretely, this also means the need to say, paraphrasing Ortega y Gasset's "I am myself and my circumstances", that "I am myself and my skeletons hidden in the cupboard". This essential ontology of corpses from the past makes our identity as much as our complex relationships in our community, in a combination of race, class, gender and sexual cultures. (...) the important point is to recognize their [sexual stories] formative importance in our lives, because they ground us theologically in dialogue with ourselves and God, and with the current ideologies which are persistently trying to suppress and distort our identities with a politics of denial. Peccadilloes are an important part of a theology of storytelling, or sexual storytelling where real experiences and fantasies get mixed. Heterosexuality is basically founded on a denial of reality, and works by creating a Christian culture of secrecy. One meaning of virginity in Mary is the denial of a past of sexual experiences. ${ }^{46}$

Marcella understands heterosexuality as the normative and universal ideology what has been called heteronormativity - that seeks to erase the sexual diversity (and all diversity for that matter) in order to create a narrative that supports the exclusion and oppression of people, mostly poor women and/or sexual "deviants" in Latin America in the name of a colonial project, currently named as neoliberal capitalism. ${ }^{47}$ If she is right - and I think she is - this also relates to the way HIV and AIDS was and is being handled by theology and the churches - hiding the skeletons in the cupboard: denying the past (and current) sexual experiences, creating (and maintaining) a culture of secrecy and reinforcing the heterosexual ideology that avoids an honest theology of sexual storytelling that intertwines race, class, gender

${ }^{45}$ Althaur-Reid, Marcella. Indecent theology. London: Routledge, 2001. p. 74.

${ }^{46}$ Althaur-Reid, 2001, p. 74.

47 According to Althaur-Reid, 2003, p. 91, "Heterosexuality is in part a tool of theological production but also a result of the process. Heterosexuality has been produced by na alignment of elements such as dualist thinking, hierarchisation, and colonial processes of displacement localized in different". So, "Heterosexuality is not a neutral science and the inner logic of the system works with its own artificially created 'either/or' concepts. It unifies the ambivalence of life into one official version. Per/versions (the different versions of a road) are silenced (Althaur-Reid, 2001, p. 13). 
and sexual cultures. Purposefully forgetting the "gay cancer" narrative and how it still impacts the social imaginary regarding the epidemic. No actual liberation theology will be possible - and actual public impact on the epidemic - if those peccadilloes (and it is obvious she is not referring to sin) are not brought to light.

Just as in the "Not even the Saint protects you" campaign. As both Ronaldo Gutierrez and Eduardo Lima point out, it is not the "religious authorities" that define the way religious language and symbols are to be used, but the sexual stories in the struggle for citizenship. Those are the peccadilloes that have the power, when taken outside the dogmatic cupboard, designed to reinforce the theological patterns of a heterosexual theology, to create another space for the production of theological knowledge. And again "forgive me, but I don't need her authorization to speak". It is in this space, with no need for external authorization, that the Saints become human, and a possibility for the creation of new meanings, based on the real lives and experiences of people and not on some ghostly stories of no-bodies. Such as Marcella Althaus-Reid's reflection on the Virgin Mary and her use in Latin American Feminist Theology.

If it is true that the first inscriptions (of hunger, pain and sexual desire) are always written in the body, one wonders how a women's theology can start with Mary, the icon of a no-body. To start with Mary is to start with an idea, a gas-like substance, a myth of a woman without a vagina which discloses in a hilarious way the fact that half of humanity has been constructed around ideas of ghostly simulacras. ${ }^{48}$

The Saints, as a fetishized idea, do not protect anybody. Their holiness does not come magically upon or inside people making love and avoid the infection by HIV, STD or hepatitis - although some religious authorities might say they do (but they of course do not have the luxury of even thinking about the smallest peccadilloes, or they hide them so well that their make believe trick convinces even themselves). That is where the "condom" comes into play. The so many times controversial and diabolically constructed piece of rubber becomes the ultimate representation of heresy, especially when associated to anything supposed to be "saint". Its materiality explodes the metaphysical ideas of the virtuous love relations between people and becomes the symbol of a theology of care. The Saints might, then, become a symbol and a discourse for safer sexual practices, accomplished in a context of love and care for one another ${ }^{49}$ There is the revelation: it fits in one's pocket! And what kind of theology is that? A "pocket theology" or a "theology of pockets".

${ }^{48}$ Althaur-Reid, 2001, p. 39.

${ }^{49}$ Another prevention campaign using religious symbols is the Spanish campaign "Blessed be the condom who takes AIDS away from the world" that pictures someone (supposedly a religious leader) 
What about what we carry in our pockets? Money, documents, pictures of loved ones, rosaries, condoms... In real life, identity, economy, love and faith are connected and have something to say to theology. As in Eduardo's remark signifying the offering (and sharing of) a condom as an act of love and care - such Christian values, Marcella Althaus-Reid speaks of those connections and the act of doing theology.

Suppose that you are feeling lonely and think that the world is not a loving place anymore. Then you decide to go to the bar after praying your novena to your saint, or to the Virgin Mary. Perhaps you are asking San Antonio for a lover and you know that at the door of the bar nobody checks for rosaries or religious stamps in your pocket. The same can be said when you are at the door of the church. They don't ask you for that old love letter that you still keep in your bag neither do they realize whose hands your loving hands like to hold. Now suppose that in your mind the church and the Latina bar somehow get mixed up with fragments of memories of the Nicene Creed and of a Christ who died of love for you some time ago contesting the fact that nobody else seems to be dying of love for you anymore.(...)

There are many sexual dissenters whose theological community is made up of the gathering of those who go to gay bars with rosaries in their pockets, or who make camp chapels in their living rooms simply because there is a cry in their lives, and a theological cry, which refuses to fit life into different compartments. (...) The search for love and for truth is a bodily one. Bodies in love add many theological insights to the quest for God and truth. ${ }^{50}$

And she sentences: it is "necessary to dismantle the sexual ideology of theology, and for theologians to come out from their closets and ground their theologies in a praxis of intellectual, living honesty. God, meanwhile, [is] also kept in God's own closet". ${ }^{51}$ That is certainly true when dealing with HIV and AIDS.

Well, it was not Church leaders or theologians that came up with a theological perspective on HIV and AIDS in the "Saints campaign" - and most of them would probably echo the words of Cardinal Dom Odilo Scherer. But that is perhaps what we most need in facing the challenge of HIV and AIDS: the theology produced in the practice of the movement and the struggle arising from the real lives of real people

holding a communion wafer and just below the same scene is depicted but in the place of the wafer there is a red condom and the words "Take it" and "Use it". This campaign also received major criticism by the Spanish Catholic Church. See Campanha contra a aids provoca Igreja Católica na Espanha. Available at: http://colunistas.ig.com.br/cip/2010/12/06/campanha-contra-a-aids-provoca-aigreja-catolica-na-espanha/. Accessed on March 4th, 2013.

${ }^{50}$ Althaur-Reid, Marcella. The queer god. London: Routledge, 2003. p. 1, 2.

${ }^{51}$ Althaur-Reid, 2003. p. 2. 
who have to face daily the challenges of staying alive in this society. A theology that needs to discover its places of revelation in other "pocket guides" which, as the saints in the advertising campaign, are constantly moving because life is constantly moving. The "polemics of the Saints" will pass. Its theological implications will pass. It is not a theology intended to be "the" answer. It is just another way of making sense of God among us.

\section{References}

Abia. Homossexualidade e AIDS no Brasil: Catálogo do Centro de Documentação e Recursos da Abia. Rio de Janeiro: Abia, 2001.

Abia. Respostas religiosas ao HIV AND AIDS no Brasil. Rio de Janeiro: Abia, 2010. Available at: http://www.abiaids.org.br/_img/media/Livreto\%20Religi\%C3\%B5es\%20completo. pdf. Acessed on: 28/05/12.

Alison, James. AIDS como lugar de revelação. In: Assman, Hugo (Ed.). René Girard com teólogas da libertação. Petrópolis/Piracicaba: Vozes/UNIMEP, 1991.

Althaur-Reid, Marcella. Indecent theology. London: Routledge, 2001.

Althaur-Reid, Marcella. The queer god. London: Routledge, 2003.

Alves, Rubem. AIDS. Tempo e Presença, Vol./No. 269, p. 52-53, 1993.

Arcebispo de SP critica o uso de imagens de santos na Parada Gay. Available at: http:// g1.globo.com/sao-paulo/noticia/2011/06/arcebispo-de-sp-critica-o-uso-de-imagensde-santos-na-parada-gay.html. Accessed on: March 3rd, 2013.

Barros, Patrícia Marcondes de. A nova consciência dos trópicos e a imprensa do desbunde. Available at: http://tropicalia.com.br/leituras-complementares/a-nova-consciencianos-tropicos-e-a-imprensa-do-desbunde. Acessed on: February 20, 2013.

Bastos, Francisco Inácio. Aids na Terceira década. Rio de Janeiro: Editora Fiocruz, 2006.

Campanha contra a aids provoca Igreja Católica na Espanha. Available at: http://colunistas.ig.com.br/cip/2010/12/06/campanha-contra-a-aids-provoca-a-igreja-catolica-naespanha/. Accessed on March 4th, 2013.

Campanha: O Amor Lança Fora Todo o Medo. Available at: http://www.koinonia.org.br/ campanha_amor.asp. Accessed on: March 4th, 2013.

Cardeal Scherer critica desrespeito à fé católica na parada gay em São Paulo. Available at: http://www.acidigital.com/noticia.php?id=22070. Acessed on March 3rd 2013.

Carrara, Sérgio; Moraes, Claudia. Um mal de folhetim. Comunicações do Iser, Rio de Janeiro, vol. 4, no 17, p. 20-26, dez 1995.

Chauí, Marilena. Brasil: Mito fundador e sociedade autoritária. 5 imp. São Paulo: Editora Perseu Abramo, 2000.

Citeli, Maria Teresa. A pesquisa sobre sexualidade e direitos sexuais no Brasil (1990-2002): Revisão crítica. Rio de Janeiro: CEPESC, 2005.

Conferência Nacional Dos Bispos Do Brasil. Pastoral DST/Aids. Viu e teve compaixão. Igreja e Aids. Fortaleza: CNBB - Pastoral DST/Aids.

Confira galeria com as imagens dos santos que causaram polêmica na Parada de SP. Available at: http://acapa.virgula.uol.com.br/cultura/confira-galeria-com-as-imagens-dos- 
santos-que-causaram-polemica-na-parada-de-sp/3/8/14038. Accessed on: March 4th, 2013.

Daniel, Herbert. AIDS no Brasil: a falência dos modelos. In: Daniel, H.; Parker, R. Aids: a Terceira epidemia. São Paulo: Iglu, 1991.

Evangelista, Márcia. "0 amor lança fora o medo...”. Published on July 21st, 2011. Abail-

able at: http://www.koinonia.org.br/comunicacao-noticias-detalhes.asp?cod=1615. Accessed on March 4th, 2013.

Fry, Peter. Pra inglês ver. Rio de Janeiro: Zahar, 1982.

Galvão, Jane. AIDS e a imprensa: um estudo de Antropologia Social. Thesis (Masters in Social Anthropology) - Graduate Program in Social Anthropology, Museu Nacional, Universidade Federal do Rio de Janeiro, 1992. Mimeo.

Galvão, Jane. AIDS no Brasil - A agenda de construção de uma epidemia. Rio de Janeiro: ABIA; São Paulo: Ed. 34, 2000.

Galvão, Jane. As respostas religiosas frente à epidemia de HIV and AIDS no Brasil. In: Parker, Richard (org.). Políticas, instituições e AIDS: enfrentando a epidemia no Brasil. Rio de Janeiro: ABIA, 1997.

Green, James N. Além do carnaval: A homossexualidade masculina no Brasil do século XX. São Paulo: Unesp, 2000.

Green, James N.; Trindade, Ronaldo (org.). Homossexualismo em São Paulo. São Paulo: Editora Unesp, 2005.

Greenbeerg, David F. The construction of homosexuality. Chicago: The University of Chicago Press, 1988.

Hernandez, Ivan Perez. Teologías de la Liberación y minorias sexuales em America Latina y el Caribe. In: Trasferetti, José (org.). Teologia e sexualidade. Campinas: Átomo, 2004.

Hunt, Mary. Bodies don’t lie: A feminist theological perspective on embodiment. Available at: http://www.wftl.org/pdf/063.pdf. Accessed on February 20, 2013.

Llistó, Paco. Fotógrafo se diz ameaçado após campanha de prevenção com imagens sacras durante Parada Gay. Published on June 27th, 2011. Available at: http://acapa.virgula. uol.com.br/mobile/noticia.asp?codigo=14015. Accessed on: March 3rd, 2013.

Mott, Luiz. Escravidão e homossexualidade. In: Vainfas, Ronaldo (org.). História e sexualidade no Brasil. Rio de Janeiro: Graal, 1986. p. 19-40.

Múscari, Marcello Felipe de Jesus. A dupla construção: A resposta à AIDS e a regulação do religioso no ' $1^{\circ}$ Seminário Aids e religião do Rio Grande do Sul'. Trabalho de Conclusão de Curso. Porto Alegre: UFRGS, 2011. Available at: http://www.lume.ufrgs.br/ bitstream/handle/10183/40398/000827246.pdf?sequence=1. Acessed on 28/05/12.

Nascimento, Dilene Raimundo do. As pestes do século XX: tuberculose e Aids no Brasil, uma história comparada. Rio de Janeiro: Ed. Fiocruz, 2005.

Ninguém é tão santo assim. Video available at: http://nemsantoteprotege.blogspot.com. br/2011/12/ninguem-e-tao-santo-assim.html. Accessed on: March 3rd, 2013.

Oliveira, Ana. Identisignificados - Movimento. Available at: http://tropicalia.com.br/identifisignificados/movimento. Acessed on: February 20, 2013.

Orozco, Yury Puello. Mulheres, AIDS e religião. São Paulo: Católicas pelo Direito de Decidir, 2002. 
Parker, Richard. Abaixo do Equador: Culturas do desejo, homossexualidade masculina e comunidade gay no Brasil. Rio de Janeiro: Record, 2002.

Pereira, Nancy Cardoso. Igrejas e Aids (2): perspectivas bíblicas e pastorais. Rio de Janeiro: Instituto de Estudos de Religião, 1990.

Revista Friday. Entrevista: Eduardo Lima: Proteção acima de religião. Available at: http:// www.revistafriday.com.br/2012/06/entrevista-eduardo-lima-protecao-cima.html. Accessed on March 3rd, 2013.

Sampaio, Tânia Mara. Aids e religião: aproximações ao tema. Impulso, Piracicaba: Editora Unimep, vol. 13, no. 32, set.-dez, 2002

Santos da polêmica. Available at: http://www.doistercos.com.br/santos-da-pole/. Accessed on March 4th, 2013.

Terto Jr. Veriano. 0 movimento social da AIDS e as novas identidades sexuais. In: PARKER, Richard; CORRÊA, Sonia (org.). Sexualidade e política na América Latina. Rio de Janeiro: ABIA, 2003. p. 97-100.

Terto Jr., Veriano. Reinventando a vida: histórias sobre homossexualidade e AIDS no Brasil. Tese de Doutorado. Rio de Janeiro: Universidade Estadual do Rio de Janeiro, 1997.

Trasferetti, José Antônio; Lima, Lívia Ribeiro. Teologia, sexualidade e Aids. Aparecida, SP: Santuário, 2009.

Trevisan, João Silvério. Devassos no paraíso: A homossexualidade no Brasil, da colônia à atualidade. Rio de Janeiro: Record, 2000.

Tunes, Suzel. Religiosos apoiam luta de homossexuais. Available at: http://www.koinonia. org.br/comunicacao-noticias-detalhes.asp?cod=1602. Accessed on March 4th, 2013.

Westhelle, Vitor. Voces de protesta en América Latina. México: CETPJDR/Lutheran School of Theology, 2000. 